\title{
EDITORIAL \\ Neurosurgical Focus: first among equals in online, freely accessible journals
}

\author{
James T. Rutka, MD, PhD \\ Editor-in-Chief, Journal of Neurosurgery Publishing Group, Charlottesville, Virginia
}

$\mathrm{T}$ HIS year marks the 20th anniversary of Neurosurgical Focus (Focus), the Journal of Neurosurgery Publishing Group's (JNSPG's) online and freely accessible journal. Focus was implemented at a time when digital publications were just coming into existence. It was the brainchild of Dr. Marty Weiss (Fig. 1), University of Southern California, who had been serving on the Editorial Board of the Journal of Neurosurgery from 1987 to 1996. Before Dr. Weiss stepped down as Chairman of the Editorial Board of the Journal of Neurosurgery, he convinced Dr. John A. Jane Sr., Editor-in-Chief of the Journal of Neurosurgery, to consider the prospects of initiating a completely digital and online journal. Dr. Weiss had been impressed with the digital communications of some of the basic science journals such as the Journal of Biological Chemistry and the American Journal of Physiology. Rather than be left behind in this realm, Dr. Weiss exhorted Dr. Jane to consider the importance of online publications. While initially somewhat skeptical as to the feasibility and viability of a completely online journal, Dr. Jane ultimately acquiesced to Dr. Weiss' insistence, and Focus was born. The name for the journal was actually a joint decision made by Drs. Weiss and Jane.

The concept of Focus is relatively straightforward. It is a topic-based online journal. Over the years, more than 220 issues on numerous topics in neurosurgery have been produced (http://thejns.org/action/showCoverGallery?jour nalCode=foc). The very first issue of Focus was posted on the AANS's website on July 1, 1996, and the topic was Pituitary Disease and Endocrine Problems, which remains a topic of great interest to Dr. Weiss. While no topic editor is listed for this issue, Dr. Weiss did the lion's share of the reviewing and editing. Following this issue, the majority of issues have been managed by invited topic editors who have helped Dr. Weiss render decisions on manuscripts for publication. Initially, the topic editors would recruit their trusted colleagues to write articles in a timely manner for the specific issue that would be posted online. However, over time, the competition for publishing one's work in Focus became increasingly greater. At this time, approximately 30-50 papers are submitted by earnest and eager authors for fewer than 20 slots per issue.

A glimpse back in time reveals important topics in neurosurgery covered in Focus including: "Cranial Nerve Surgery" (August 1996); "Molecular Biology for Neurosurgeons" (September 1997); "Carotid Vascular Disease" (December 1998); and "Syringomyelia" (March 2000). The advantage of topic-based online publishing is the ability to bring state-of-the-art manuscripts on a single topic swiftly to publication. Examples of this feature of Focus include such topics as "Socioeconomic Issues in Neurosurgery" (April 2002); "Bioabsorbable Devices in Spinal and Cranial Neurosurgery" (March 2004); "Stem Cell Opportunities in Neurosurgery" (September 2005); "Hypothalamic Hamartomas" (February 2011); and "Risk Prevention and Surgical Checklists" (November 2012).

This year marks the 20th anniversary of Dr. Weiss' tenure as Editor of the Journal of Neurosurgery and Focus. We owe him a great debt of gratitude for what he has accomplished with the first fully online and freely accessible journals in the clinical neurosciences. For the past 20 years, Dr. Weiss has selected every topic for Focus and has helped shape the field of digital, online publications in the neurosciences accordingly.

How can the success of Focus be measured objectively? Consider the following bibliometrics: 1) Between 2009 and 2015, there have been 1,378,096 Abstract accesses, and 3,254,323 full-text accesses; 2) between 2010 and 2014, Focus' Impact Factor has ranged between 2.105 and 2.867 ; 3) average citations per article are 7.8 ; 4) Focus' H- 


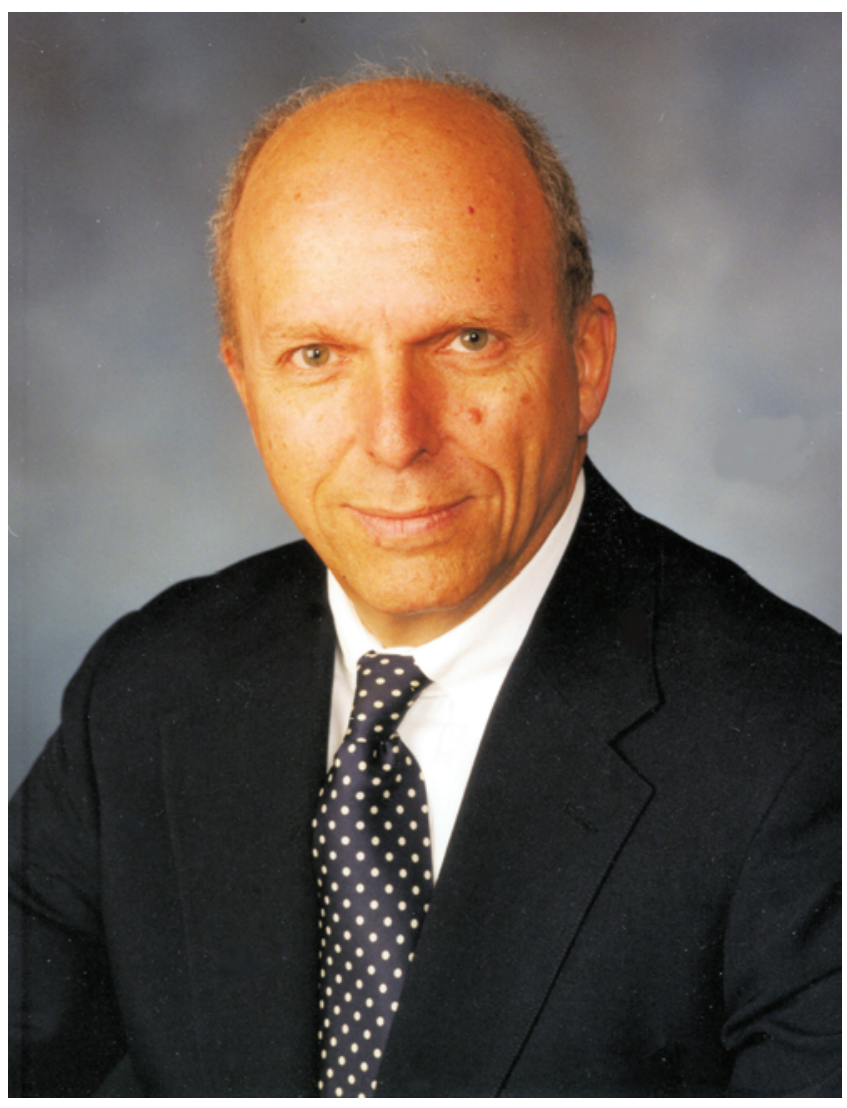

FIG. 1. Dr. Martin Weiss, Editor of Neurosurgical Focus from 1996 to 2016. Reproduced with permission from the University of Southern California, Department of Neurosurgery, and Dr. Weiss.

index is 37 ; and 5) the number of countries represented by people visiting Focus' website is 238 , indicating its worldwide appeal. The top 5 most highly cited articles in Focus are listed in Table 1. Each of these has received 100 or more citations.

The transition for editorial leadership of Focus has now been established. We welcome Dr. William Couldwell (Fig. 2) as the new Editor of Focus. Dr. Couldwell is a past President of the AANS (2013-2014), Chair of the De-

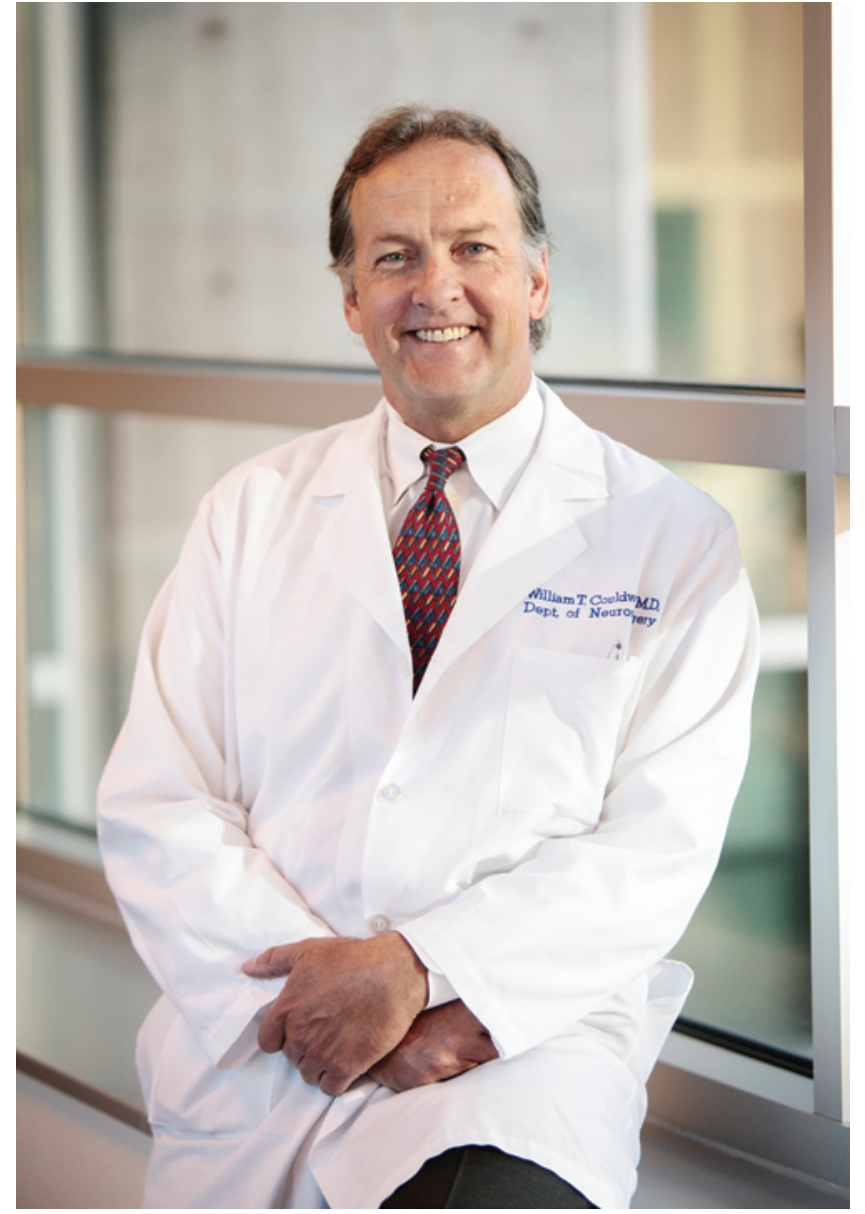

FIG. 2. Dr. William Couldwell, Editor of Neurosurgical Focus starting in 2016. Reproduced with permission from the University of Utah, Department of Neurosurgery.

partment of Surgery at the University of Utah, and former Chair of the Editorial Board of the Journal of Neurosurgery in 2007. He will be ably assisted in his new position by his Associate Editors, Dr. Jason Sheehan, Professor of Neurosurgery at the University of Virginia (Fig. 3 left), and Dr. Aaron Cohen-Gadol, Professor of Neurosurgery at

\section{TABLE 1. Top 5 most highly cited publications in Neurosurgical Focus}

\begin{tabular}{|c|c|c|c|c|}
\hline Title & Authors & $\begin{array}{l}\text { Publication } \\
\text { Year }\end{array}$ & $\begin{array}{c}\text { Total } \\
\text { Citations }\end{array}$ & $\begin{array}{l}\text { Average } \\
\text { per Year }\end{array}$ \\
\hline $\begin{array}{l}\text { Current status of acute spinal cord injury pathophysiology and } \\
\text { emerging therapies: promise on the horizon }\end{array}$ & $\begin{array}{l}\text { Rowland, James W.; Hawryluk, Gregory W. J.; } \\
\text { Kwon, Brian; Fehlings, Michael G. }\end{array}$ & 2008 & 182 & 20.2 \\
\hline $\begin{array}{l}\text { Complications of cranioplasty following decompressive crani- } \\
\text { ectomy: analysis of } 62 \text { cases }\end{array}$ & $\begin{array}{l}\text { Gooch, M. Reid; Gin, Greg E.; Kenning, Tyler J.; } \\
\text { German, John W. }\end{array}$ & 2009 & 113 & 14.12 \\
\hline $\begin{array}{l}\text { Protection and repair of the injured spinal cord: a review of } \\
\text { completed, ongoing, and planned clinical trials for acute } \\
\text { spinal cord injury: a review }\end{array}$ & $\begin{array}{l}\text { Hawryluk, Gregory W. J.; Rowland, James; } \\
\text { Kwon, Brian K.; Fehlings, Michael G. }\end{array}$ & 2008 & 110 & 12.2 \\
\hline $\begin{array}{l}\text { Early outcomes and safety of the minimally invasive, lateral } \\
\text { retroperitoneal transpsoas approach for adult degenerative } \\
\text { scoliosis }\end{array}$ & $\begin{array}{l}\text { Dakwar, Elias; Cardona, Rafael F.; Smith, } \\
\text { Donald A.; Uribe, Juan S. }\end{array}$ & 2010 & 102 & 14.6 \\
\hline $\begin{array}{l}\text { Complications of decompressive craniectomy for traumatic } \\
\text { brain injury }\end{array}$ & Stiver, Shirley I. & 2009 & 100 & 12.5 \\
\hline
\end{tabular}




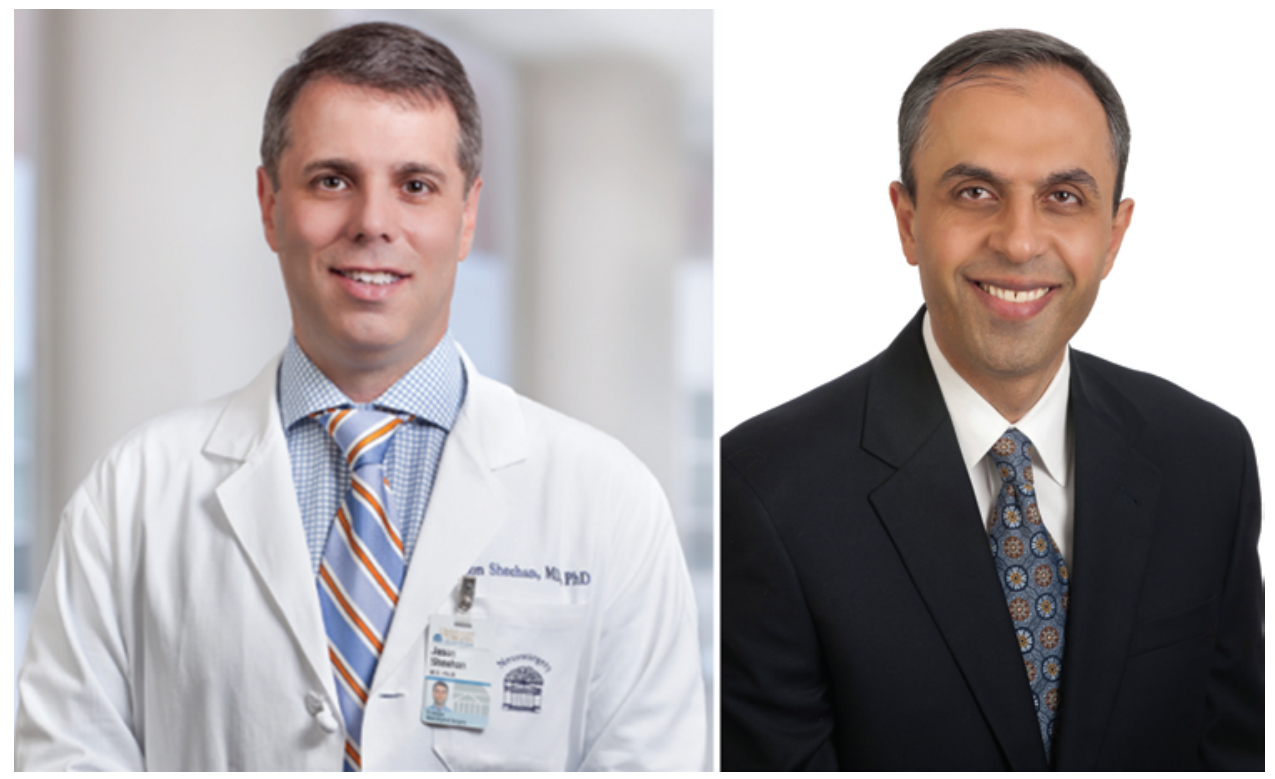

FIG. 3. Left: Dr. Jason Sheehan, Associate Editor of Neurosurgical Focus. Reproduced courtesy of the University of Virginia, Department of Neurosurgery, with permission from Jackson Bruce Smith. Right: Dr. Aaron Cohen-Gadol, Associate Editor of Neurosurgical Focus. Reproduced courtesy of Goodman Campbell Brain and Spine Institute, with permission from Dr. Cohen-Gadol.

the University of Indiana (Fig. 3 right). Together, this team will be guiding Focus through a completely new era in digital publications. Already, Focus has shown great leadership and innovation in the publication of video materials through the biannual video supplements that are edited by Dr. Sander Connolly, Professor of Neurosurgery at Columbia University (Fig. 4). Focus video supplements now house 146 videos on YouTube. As of January 2016, these have enjoyed more than 45,000 views.

Just as I thank Dr. Weiss for his tremendous leadership of Focus these past 20 years, so too do I look forward to working with the new team of Focus under Dr. Couldwell's guidance and visionary approach to online publications. In my mind, Focus has proven itself as first among equals in online publishing. How it stays ahead of the curve in the years ahead will be educational and informative to all.

http://thejns.org/doi/abs/10.3171/2016.1.FOCUS1615

\section{Disclosures}

The author reports no conflict of interest.

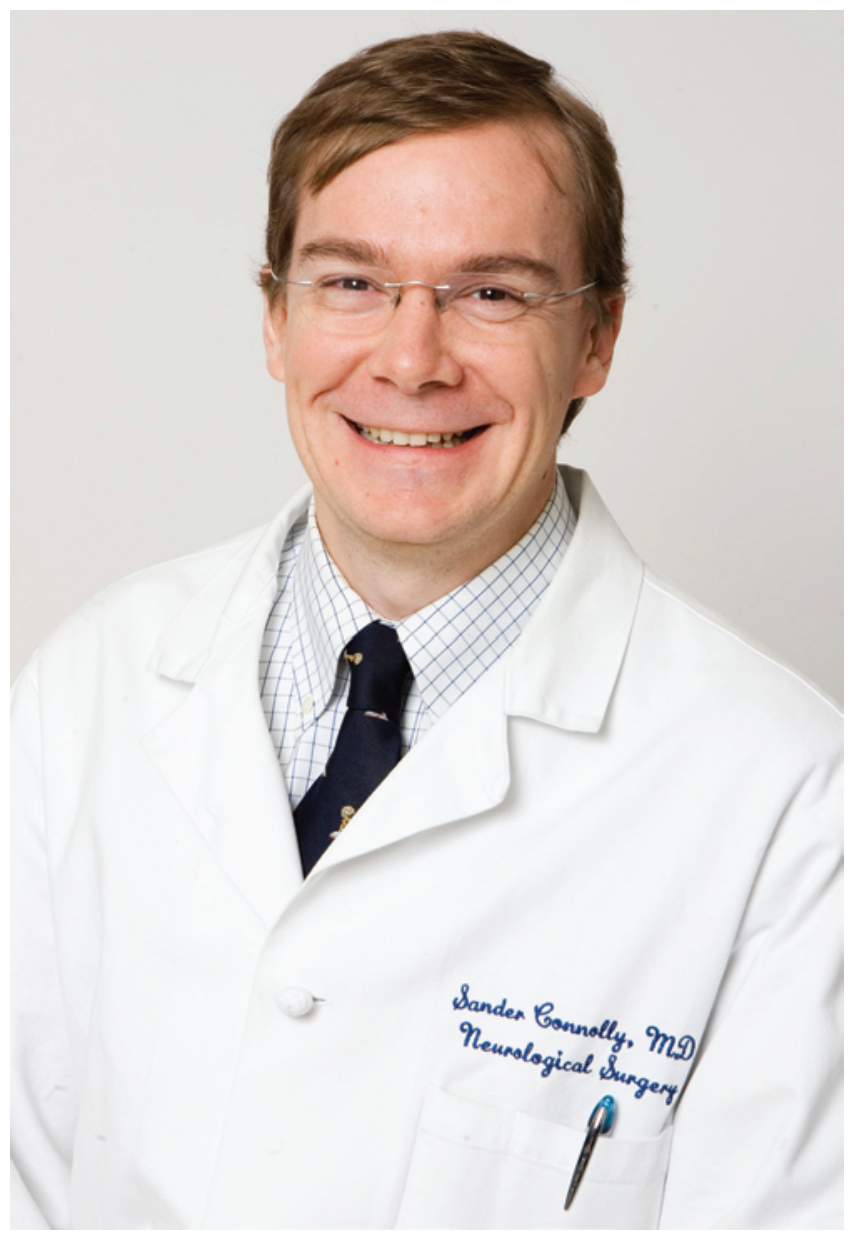

FIG. 4. Dr. Sander Connolly, Chairman of video supplements, Neurosurgical Focus. Reproduced with permission from Columbia University, Department of Neurosurgery. 